\title{
Analysis of Market Rental Property Selected Fragment in Krakow Premises in Terms of Sector Student***
}

\section{Introduction}

The market of apartments rent in the capital city of Małopolska for several years has been characterized by a stability of prices. However, examining thoroughly the shaping of rates of rental of different types of apartments over the quarters, it is possible to see that this market is characterized also by a high seasonality. The undeniable association with this is the fact that the most numerous group of tenants are students. Their considerable part tries to avoid the payment of the apartment in the holiday period. The decrease in the demand causes a temporary reduction in prices, since for the owners the rent of the apartment for the summer period for a lower amount is much more beneficial than sustaining the fixed costs for 3 months. The students returning for the winter semester attempt to obtain the best accommodation in a convenient location and at an inexpensive price. It is also then that they encounter a significant growth in prices caused by a rapid growth in demand.

In the questionnaire published on the website KRN.pl concerning the degree of difficulties of finding a satisfactory offer of rent of apartments $34.3 \%$ percent of respondents considered this as "very difficult" to perform, $31.42 \%$ considered that it is "rather difficult". Probably the issue, which causes the most problems, is the uneven relation of financial predispositions of the alleged tenants to the expected attributes of the apartment. Usually the price for the apartment of low standard in the city centre is comparable with the one that should be paid for the rental of a well furnished apartment located in more distant districts. Another issue is also the inadequate conviction of the owner about the attractiveness of his apartments in relation to the real condition. Only 31.42 percent of the surveyed considered that finding an offer corresponding to their requirements is "easy". Perhaps they have used the offers

\footnotetext{
* AGH University of Science and Technology (student), Krakow, Poland

** AGH University of Science and Technology, Faculty of Mining Surveying and Environmental Engineering, Department of Geomatics, Krakow, Poland

*** Article is part of a grant dean No. 15.11.150.322/16
} 
of tenants who are able to adjust the conditions and price to the current market standards. The alternative option is also the knowledge of these people concerning the rent market, in order to create greater chances of an easier and quicker finding of the satisfactory apartment, market studies of apartments rent in Krakow were conducted.

In order to thoroughly analyse the preferences of the most numerous group among the potential tenants, namely the students, a survey was conducted. The asked questions referred to the location, standard communication accessibility, surface and prices of the apartments rented by them $[1,4,8]$.

\section{Characteristics of Collected Data and the Applied Algorithm}

\subsection{Analysis of the Survey}

As a result of the conducted survey information was collected about 600 real estates. Initially, 92 records were excluded and data from 507 people renting a part, or the entire apartment were subjected to a final statistical analysis. Thanks to the conducted study a model of optimal residential place was created both for the tenant and the lessor. The data are presented in a descriptive manner - according to the survey and in parallel they were presented in a numerical scale, using the following coding (Tab. 1).

Table 1. Features leasing transactions included in the survey

\begin{tabular}{|l|l||}
\hline \multicolumn{1}{|c|}{ Attribute } & \multicolumn{1}{|c|}{ The method of assigning numeric values } \\
\hline \hline Date of signing the contract of rent & Not included directly in the analysis \\
\hline Time of transaction [months] & $\begin{array}{l}\text { Counted as the number of months that passed by since the first } \\
\text { transaction in the database (from July 2007) }\end{array}$ \\
\hline Time of rental [months] & $\begin{array}{l}\text { Counted as the number of months, for which the agreement was } \\
\text { concluded }\end{array}$ \\
\hline The apartment was rented: & $\begin{array}{l}\text { Via real estate agency: }-1 \\
\text { Directly from the owner: } 1\end{array}$ \\
\hline Number of rooms in the apartment & As the integer, the studio flat was assigned the value of 1 \\
\hline Urban unit & Attribute of nominal nature \\
\hline Surface of the apartment & $\begin{array}{l}\text { As the maximum value of the stated scope, for surfaces above } \\
80 \text { m the adopted value is } 100\end{array}$ \\
\hline The price for rental of the whole \\
apartment [PLN] & $\begin{array}{l}\text { The price which shall be borne by the lessor, includes the } \\
\text { compensation for the owner and the administration rent }\end{array}$ \\
\hline Surface of the room & $\begin{array}{l}\text { As the maximum value of the stated scope, for the studio flats the } \\
\text { metric area of } 20 \text { m }{ }^{2} \text { was adopted }\end{array}$ \\
\hline
\end{tabular}


Table 1 cont.

\begin{tabular}{|l|l||}
\hline $\begin{array}{l}\text { The price for rental of a room } \\
\text { [PLN] }\end{array}$ & $\begin{array}{l}\text { The price which is paid by } 1 \text { person residing in a given room/ } \\
\text { apartment }\end{array}$ \\
\hline Type of room & $\begin{array}{l}\text { The number of people that may live in one room, for transitive } \\
\text { rooms this value was increased by 0.5 }\end{array}$ \\
\hline Technical standard & $\begin{array}{l}\text { Presented in an ordinal scale of five stages, expressed } \\
\text { numerically as follows: very good (5), good (3), moderate (1), } \\
\text { poor (0), very poor (-1) }\end{array}$ \\
\hline Neighbourhood & $\begin{array}{l}\text { Presented in an ordinal scale of five stages, expressed } \\
\text { numerically as follows: very good (5), good (3), moderate (1), } \\
\text { poor (0), very poor (-1) }\end{array}$ \\
\hline Transport & $\begin{array}{l}\text { Presented in an ordinal scale of five stages, expressed } \\
\text { numerically as follows: very good (5), good (3), moderate (1), } \\
\text { poor (0), very poor (-1) }\end{array}$ \\
\hline
\end{tabular}

In order to determine the distribution of prices of rental of the whole apartment and its parts the chi-square test was conducted, whose results along with a histogram was presented in Figures 1 and 2.

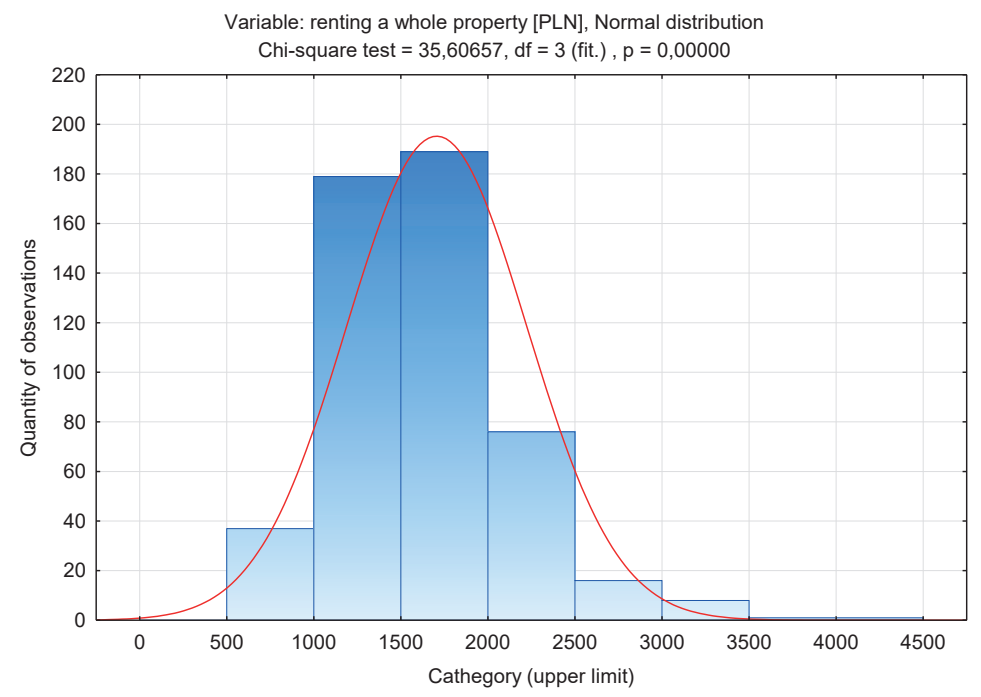

Fig. 1. Histogram rents the whole apartment

On the basis of the presented layouts it may be concluded that the interviewers are willing to select the segment of cheaper real estate - "student flats". Therefore, the histogram of rental prices resembles the gamma distribution, and not a normal distribution [7]. In further part, the variable price of rental shall be adopted as a dependent variable. 


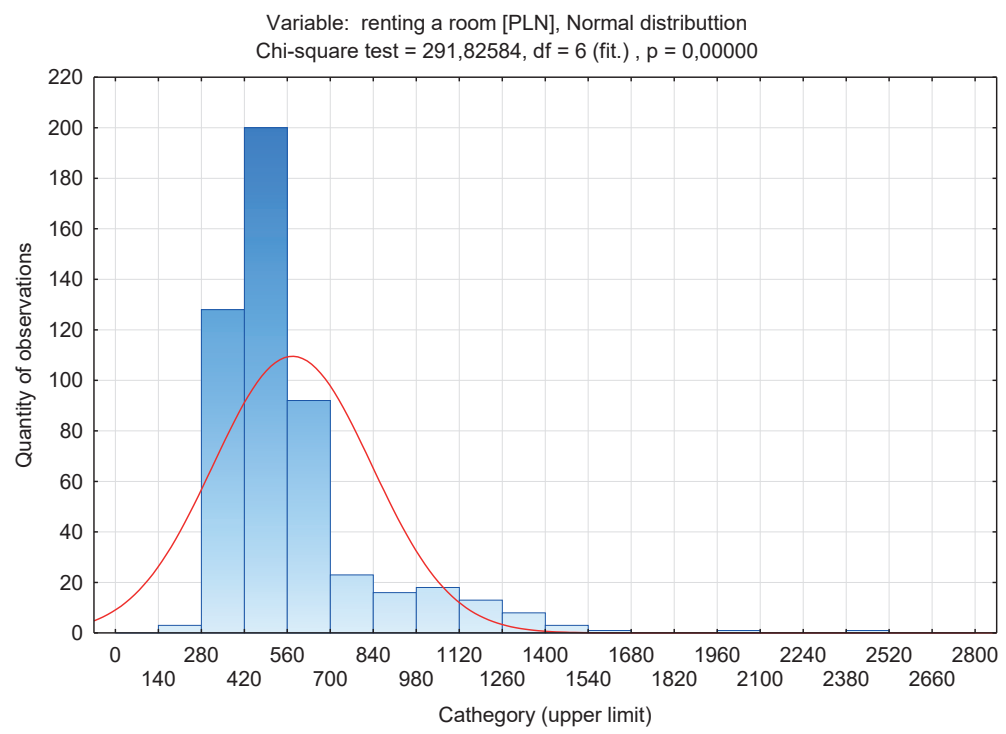

Fig. 2. Histogram rents a room (chamber)

Table 2. The Pearson correlation coefficient between the prices of rental units and selected features

\begin{tabular}{|c|c|c|c|c|c|c|c|c|c|c|}
\hline \multirow[b]{2}{*}{ Variable } & \multicolumn{10}{|c|}{$\begin{array}{c}\text { Correlations (statistical data) } \\
\text { marked by the coefficient of correlation } \\
\text { are valid with } p<.05000, N=507 \text { (lacks of data were removed in cases) }\end{array}$} \\
\hline & 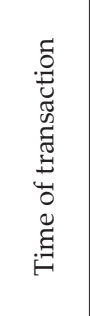 & 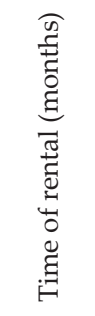 & 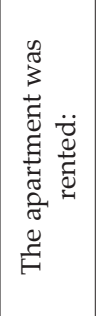 & 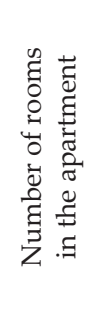 & 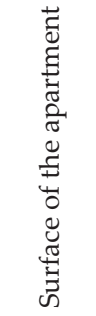 & 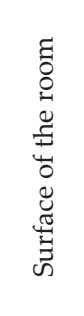 & 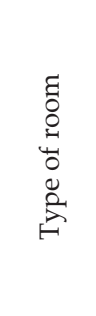 & 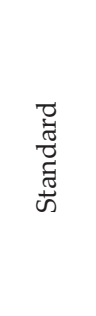 & 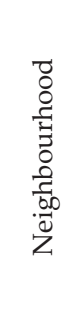 & 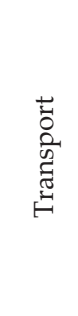 \\
\hline $\begin{array}{l}\text { The rent of } \\
\text { the room } \\
\text { [PLN/person] }\end{array}$ & -0.004 & 0.045 & -0.115 & -0.414 & -0.307 & 0.007 & -0.719 & 0.095 & 0.049 & 0.020 \\
\hline $\begin{array}{l}\text { The rent of } \\
\text { the whole the } \\
\text { apartment [PLN] }\end{array}$ & 0.086 & -0.088 & 0.003 & 0.575 & 0.454 & 0.028 & 0.275 & -0.036 & 0.012 & 0.077 \\
\hline
\end{tabular}


The statistical analysis was made in two ways - first, based on to the coefficient of correlation and based on the features expressed in the numeric scale, the second adopting the ordinal and nominal scales - creating a tree of classification (C\&RT) that enables the creation of a rule of questions conducting to identify the amount of rent of the apartment. To get a better look at the relationship between the price of the lease and the factors affecting it made the selection, resulting in the following table.

Significant correlations at the level of probability $p=0.95$ are marked in red.

Analyzing the Table 2 it is possible to easily note the following:

- The time of transaction nearly unnoticeably influences the price of rental of the whole apartment. Thus, it may be said that the average rates have been stable in the recent years [1].

- When signing the contract for a long period of time, the owners are willing to negotiate, as opposed to the rental for a short period of time.

- The difference in the method of looking for the apartment (individually or via intermediary) does not seem to have any impact on the shaping of prices (it is determined by the owner of the premises, however, it is important to remember the commission for the broker that is not included in these analyses).

- An obvious dependence is the fact that the number of rooms in the apartment increases the amount that should be paid for its rent.

- By analogy as in the previous case, the price is affected by the surface of the apartment.

- To the surprise of many it turns out that in the case of renting the whole apartment the standard and the environment do not have a large effect on the price.

- Good communication is favourable to the growth in prices for rent.

In order to analyse the preferences of real estate tenants, using the coefficient of correlation, it was necessary first of all to arrange the administrative units. It is a difficult and subjective process [3]. It is also frequently skipped as in the above case. The second method of analysis is thus the division of the market of rent, based on regression trees (C\&RT), which allows for the joining of quantitative and qualitative characteristics, without the need of assigning numeric values to all attributes. An additional advantage of classification trees is the fact that they do not require a normal distribution, they introduce rules of division resulting in the specification of the prices of rent, stating at the same time the variance and quantity in the interchange. The first step was the establishment of trees with maximum dimensions, consisting of 12 nodes divided, at 13 final. This diagram allows with high accuracy to describe the mutual connotations between the attributes describing the rented real estate, but it has too many details [5]. For this reason, it was decided to remove the number, price and surface of rooms correlated with other features. In this way, the classification tree was created with 8 interchanges divided and 9 final (Fig. 3). 
8 nodes shared, 9 terminal nodes

Model: C\&RT

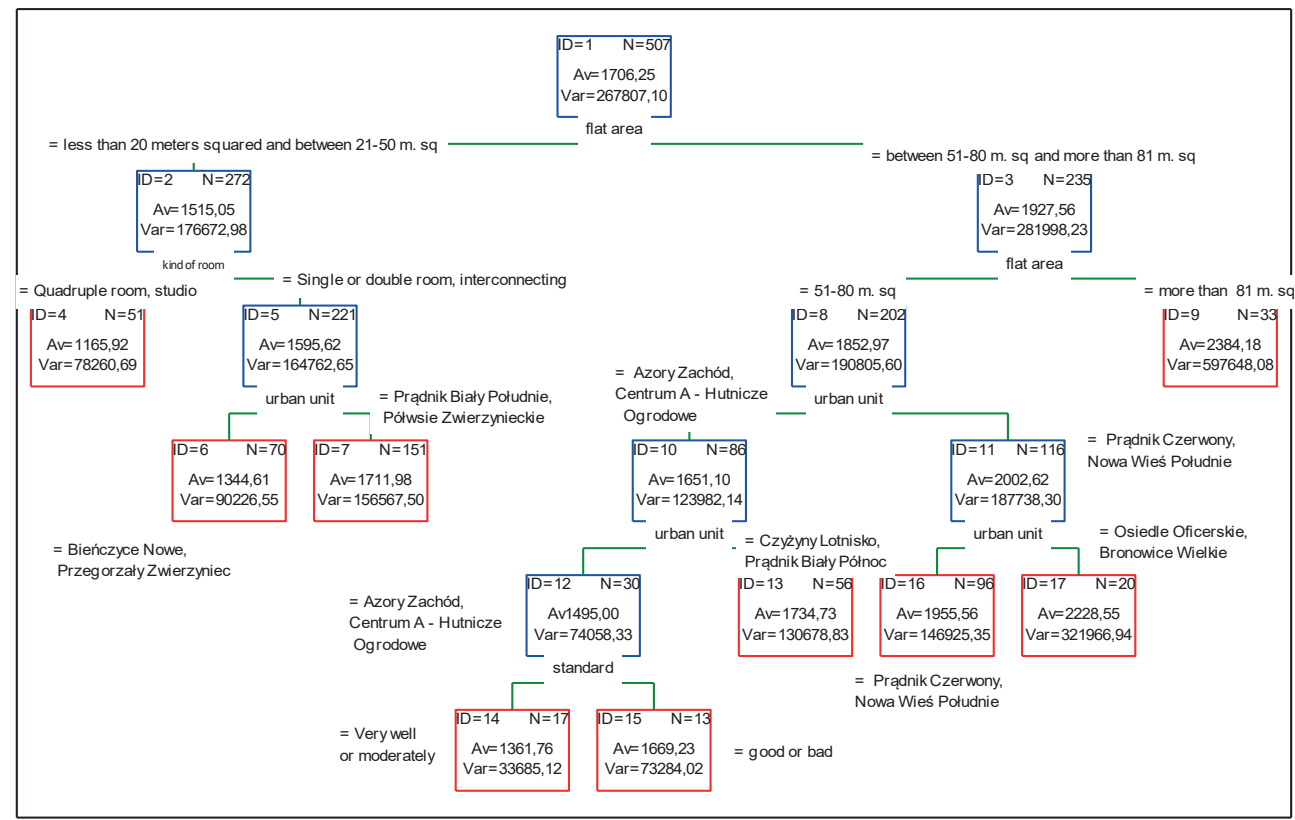

Fig. 3. Classification tree showing the formation of rents one room

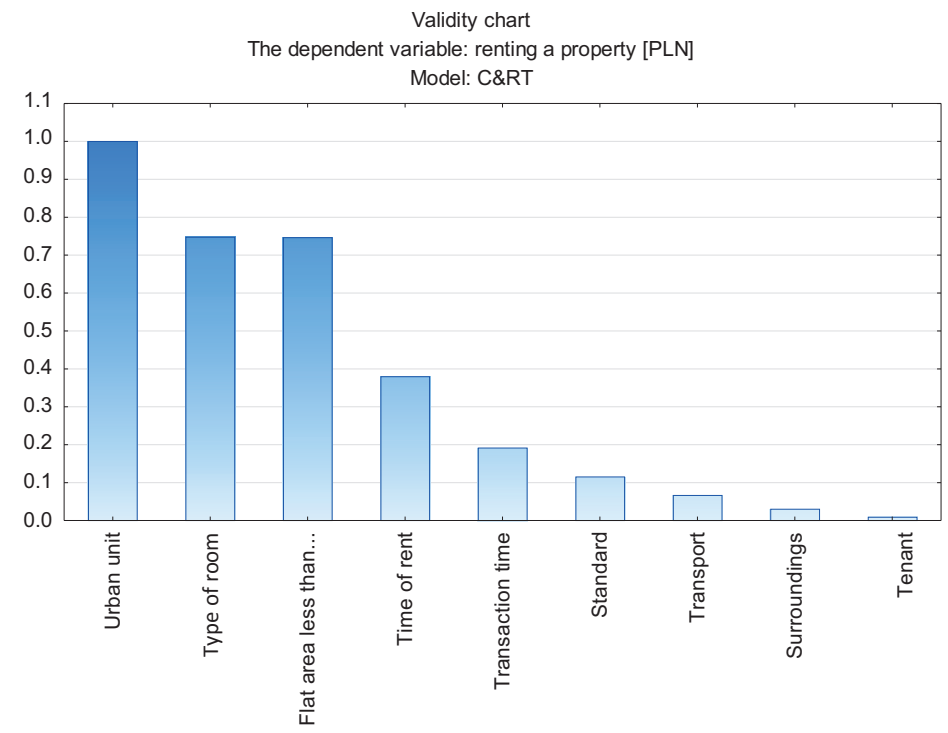

Fig. 4. Chart validity of the attributes that affect the rental price one-room 
The chart of validity of attributes presented in Figure 4 enables their arrangement according to the prediction skills. The attribute which was the most difficult to illustrate in a quantitative manner, turned out to be the most important factor. Subsequent places were occupied by "type of room" and "surface of the apartment". The lowest rank, due to a minute impact on the shaping of the price for the rent, was given to the attribute "renting from", specifying whether the apartment was found by own search for or whether this task was ordered to a real estate agency.

\subsection{The Look at the Problem from the Side of the Lessor}

This part of the study presents the characteristics of the market of rent of student flats, the preferences followed by young people when searching for apartments for the time of education at universities. The search for a relevant apartment in the period of holidays for most students is a pretty challenge. What should be preferably considered in order to avoid dissatisfaction, overpaying and fruitless time loss? What can the owner of the apartment improve in order to become more attractive for a potential tenant?

On the basis of all collected answers it was defined that for the rent of a "students' apartment" being a studio flat, it should be paid on average PLN 1174, and for an apartment consisting of 2, 3, 4 rooms - subsequently PLN 1580, PLN 1964 and PLN 2235. Figure 5 presents how these prices changed in previous years (for 1, 2, 3, and 4 rooms). It can be noted that in every case there is a delicate growth in prices.

2750 PLN

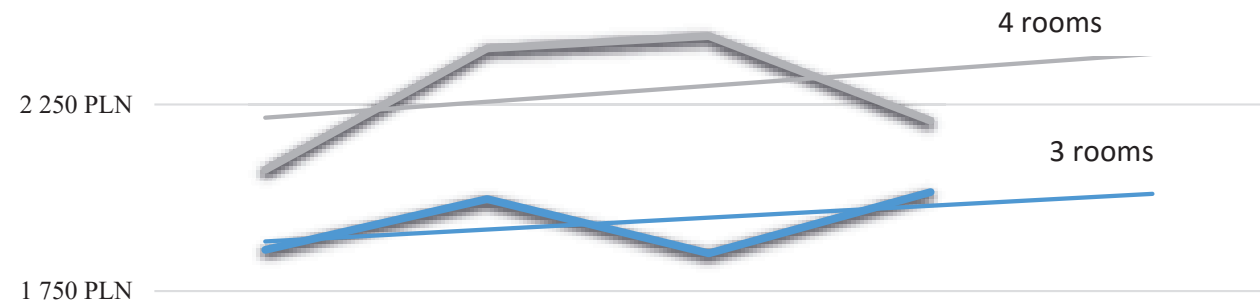

2 rooms

1250 PLN

1 room

750 PLN

$<2012$

2013

2014

2015

Fig. 5. The average price of renting an apartment 


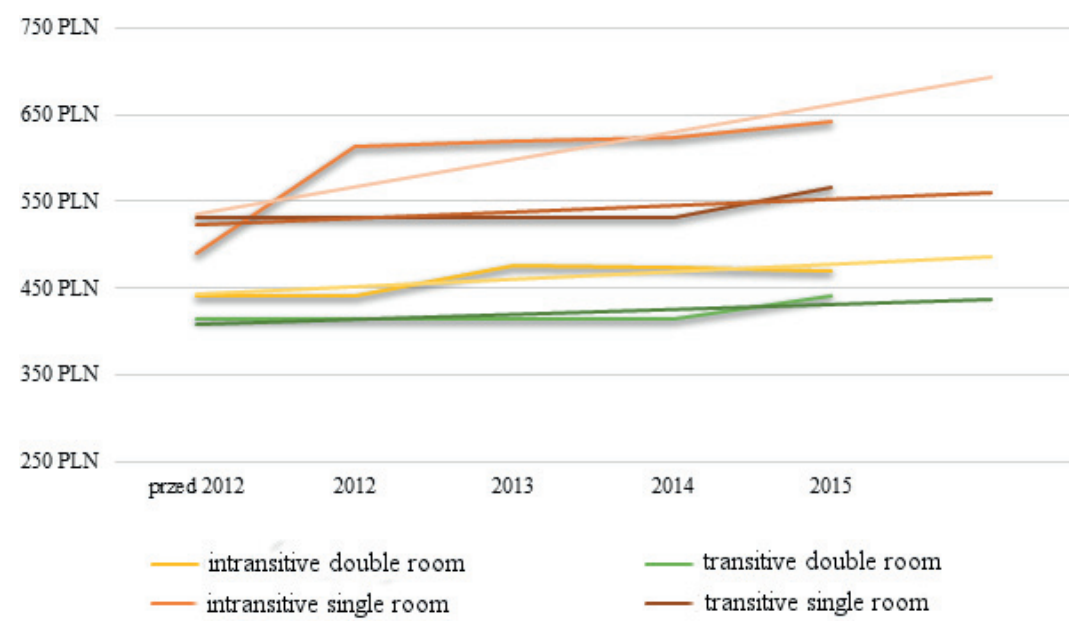

Fig. 6. The average price for renting a room

Figure 6 presents medium prices for a room in the last 4 years. Every time the prices of rent are presented they contain compensations for the owner and a rent for the cooperative.

It is a commonly known fact that the decisive impact on the real estate value is its location. This is reflected also in the rental. The already experienced students were asked in the conducted survey in which urban units they rented an apartment. It turned out that the most often selected districts are Prądnik Czerwony and Krowodrza - Nowa Wieś (5.5\%), subsequently the Stare Miasto (4.8\%), Nowa Wieś Południe and Krowodrza Południe (4.3\%). The following map (Fig. 7) presents the density of the apartments rented by the respondents of the survey.

When selecting the location, it should be, however, remembered that for an apartment with a lower standard situated closer to the town centre one shall pay approximately as much as for an apartment with higher standard in a further part of the city. Most of the students appreciate the comfort of going to classes on foot. However, it has to be paid for such a convenience. Those who want to significantly save on the fees for monthly rent should select apartments located farther from the university, however, with a direct transport connection. For the rent of an apartment with 2 room in the District I - Stare Miasto it should be paid PLN 1756. For comparison, the rent of the same flat on Prądnik Czerwony (district III) was PLN 1562, and on Podgórze Duchackie (district XI) only PLN 1257. The situation looks similar for apartments with 3 rooms.

The analysis of the results allows everyone to notice that an easy way to save money is the selection of a more remote district. Figures 8 and 9 show the dependence of the costs borne by a single person, from the location of the apartment. To compile selected ten to the urban areas in which respondents most frequently signed agreements for lease. 


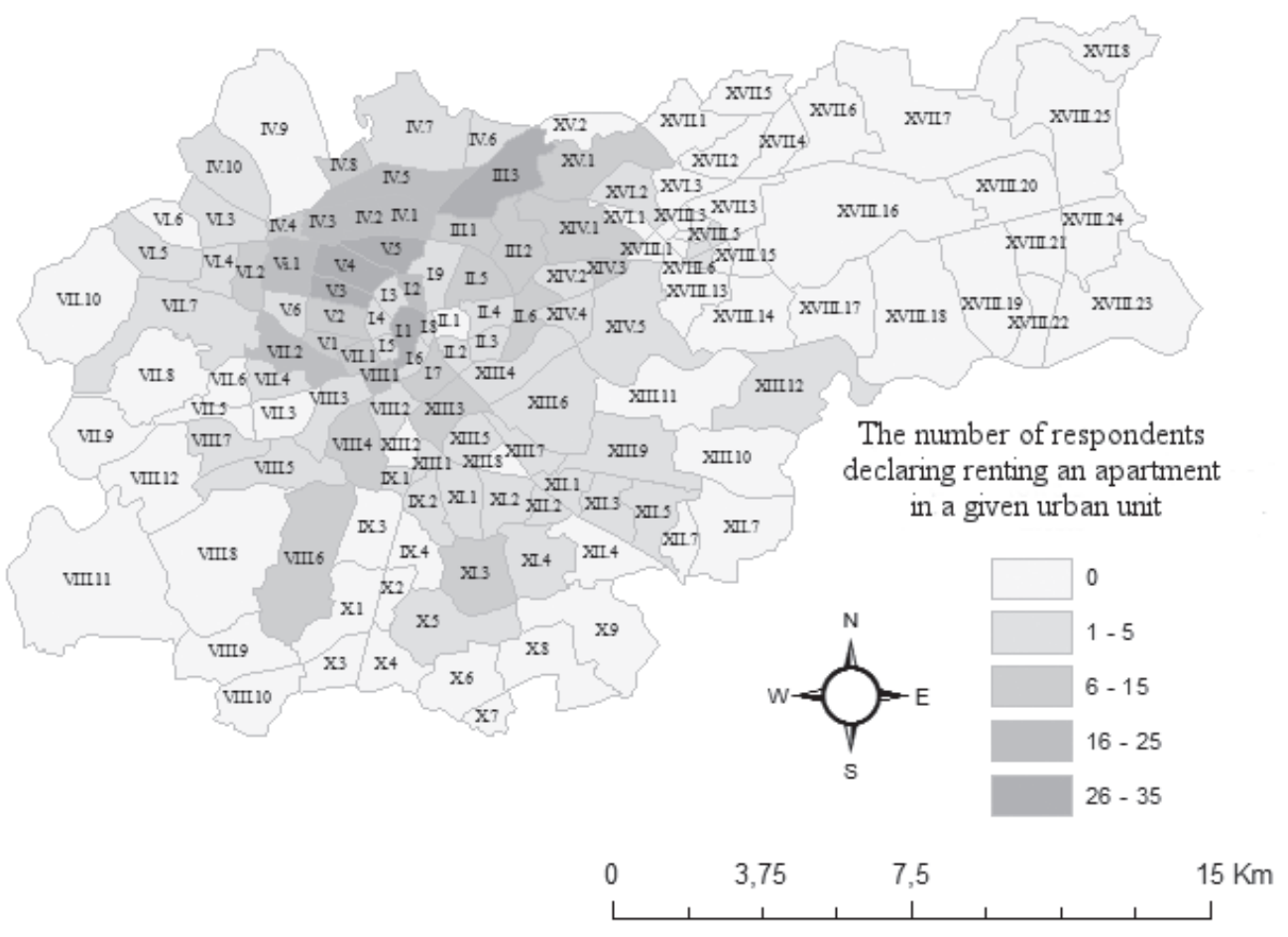

Fig. 7. Locations preferred in Krakow

Source: own study based on survey data

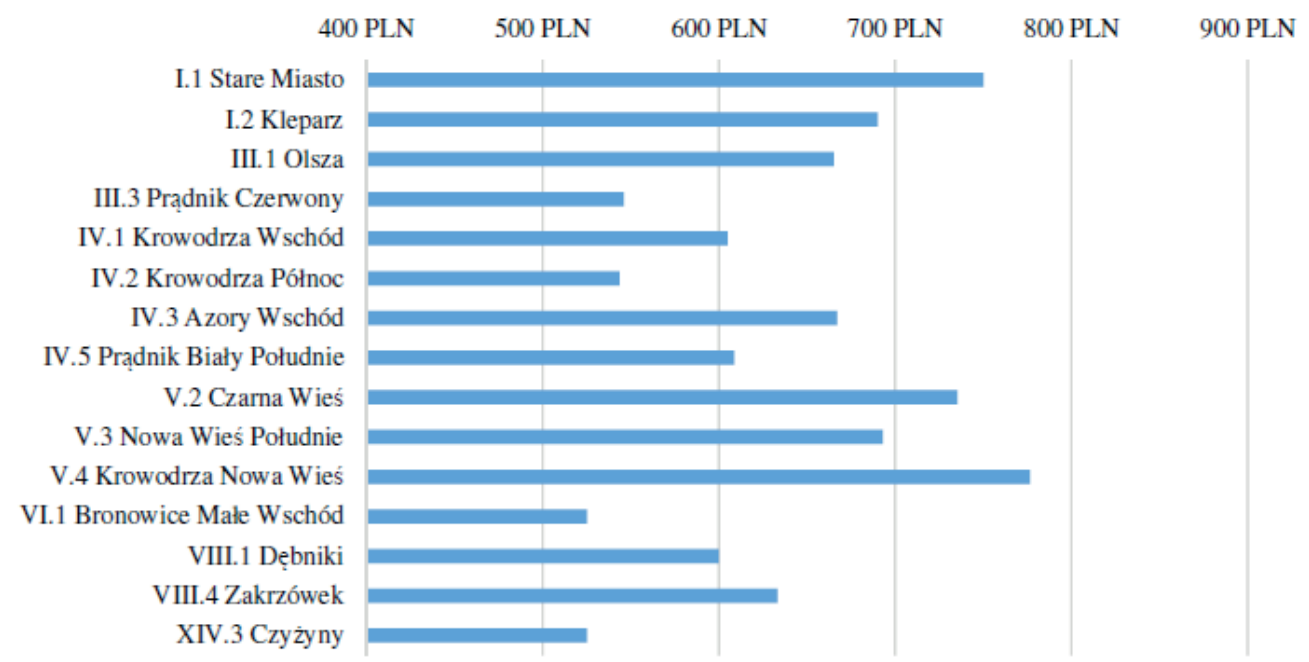

Fig. 8. Average rental prices for the whole apartment 


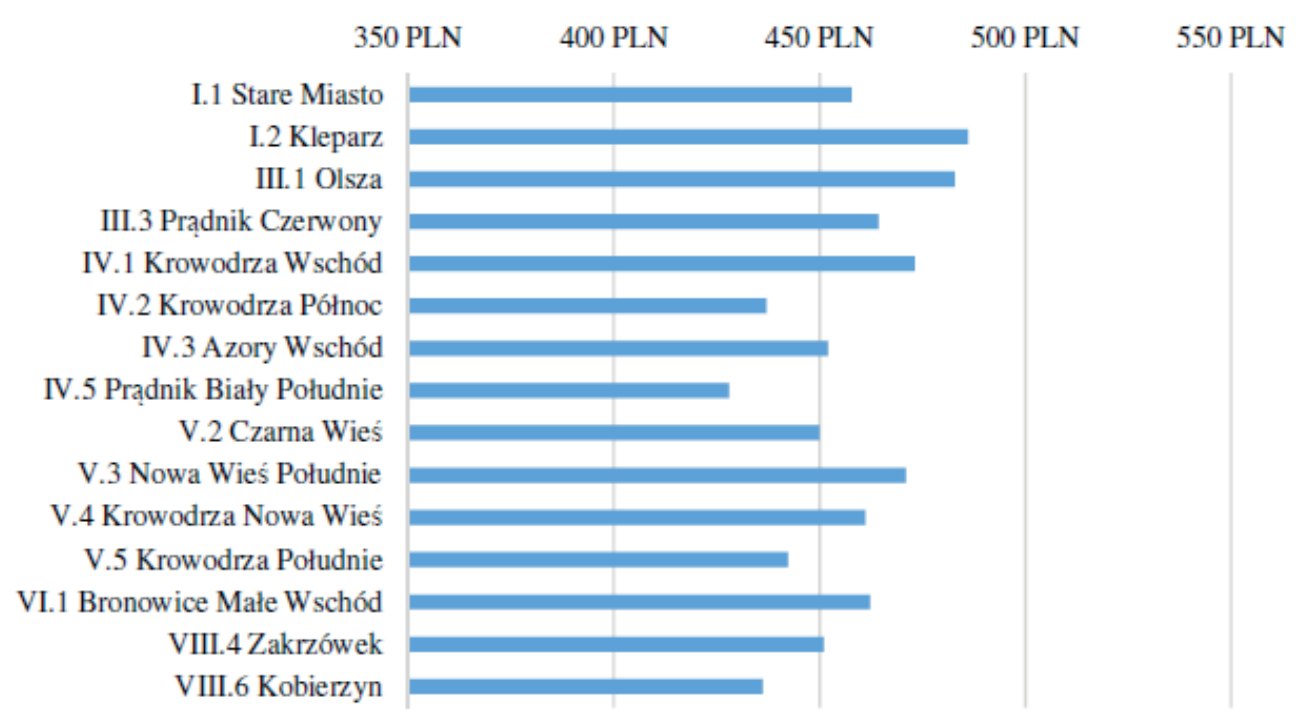

Fig. 9. Average rental prices for the room

The most popular among the renting students are apartments with 2 rooms, in the offer of apartments intended for rent in 2014 they constituted $48 \%$. The second place, however, with a significant drop have apartments with 1 room $-26 \%$, just before the apartments with 3 room $-23 \%$. The smallest group in the offer of apartments for rent are apartments with 4 room, therefore they will be the most difficult to find.

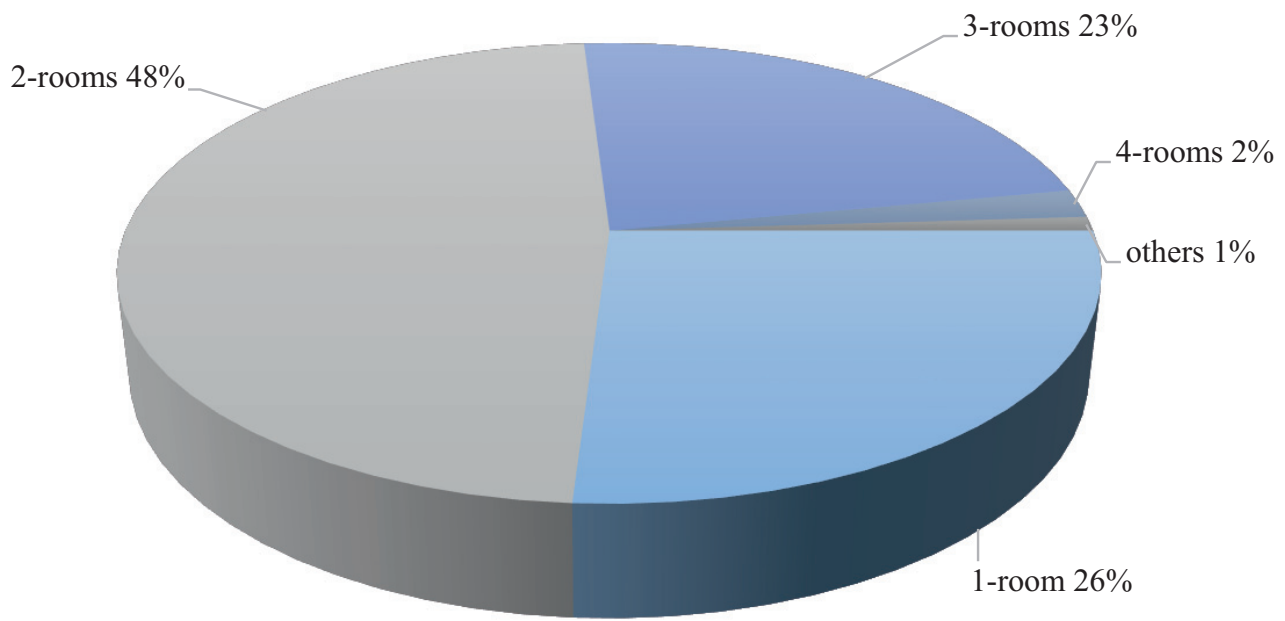

Fig. 10. The supply of apartments for rent in 2014, taking into account the number of rooms Source: data from KRN.pl [6] 
One of the urban units, in which the respondents most often rented apartments is Nowa Wieś Południe. It is in the district V Krowodrza, limited from the south by the streets Czarnowiejska, Nawojki, from the west Piastowska, from the north by the streets Podchorążych and Królewska, while from the east by al. Adama Mickiewicza. For the purpose of the study an evaluation was conducted for an apartment with 1 and 2 rooms located in the concerned unit, subsequently on the streets Czarnowiejska and Leopolda Staffa. These real estates are in the neighbourhood of such universities as University of Science and Technologgy, Technological University of Krakow and Pedagogical University. They are currently rented by the students.

In the process of evaluation five factors of forming the price were chosen: location, environment, technical standard, surface, storey and transport availability. The price of apartments was determined on the basis of 11 similar apartments, by two methods - average price correction and static analysis of the market.

As a result of the valuation it was estimated that the market value of the right to the property of a smaller apartment is PLN 186 898.35, on the other hand of a bigger apartment - PLN 291 561.43. Assuming that these real estates were rented for an average price in a given district corresponding to the number of rooms - PLN 1250 (studio apartment) and PLN 1504 (apartment with 2 rooms), knowing the amount to be paid for the rent to the cooperative is by analogy PLN 200, PLN 304 it is easy to calculate, using a financial calculator, the period over which will the apartment have to be rented in order to repay the mortgage loaned for its purchase.

The following assumptions were adopted for the calculations:

- according to the recommendation of the Polish Financial Supervision Authority it is necessary to make own contribution of at least $10 \%$, thus as "the credit amount" the value of the real estate reduced by the required own contribution was entered;

- the commission increases the credit amount;

- the amount of commission is $1.5 \%$;

- the credit interest is $3.5 \%$.

Then it was calculated, so that by manipulating the number of repayment credit years one obtains the monthly size of instalment for the compensation for the real estate owner. As a result it was demonstrated, that an apartment with 1 room in order to repay the due amounts it should be rented for 18 years, on the other hand to repay the loan for the apartment with 2 room, it would have to be rented for 29 years. An additional advantage of the smaller flat is the fact that the calculation of costs of refurbishment have not been included a refurbishment that, assuming that the standard of apartments shall be the same, for a smaller surface shall, of course, be smaller.

On the basis of one urban unit, it is possible to assume that the rental of similar students' apartments in other districts will be similar. The difference of repayment of the credit came too high in order so that the situation could reverse. To sum up, 
the purchase and intended use for rent of an apartment with 1 rooms, is much more beneficial than of a bigger apartment with 2 rooms. In case of doubts regarding the location of the purchased real estate Figure 7, placed earlier in the study, presents urban units in Krakow most often chosen by the surveyed.

\section{Summary}

The market of rent can be described as seasonal due to a large number of students living here for the time of studies. Beyond the holiday period this market is characterized by a stability of prices. During the statistical analysis it was noticed that the urban unit that can be clarified thanks to the use of regression trees has the greatest impact on the price of the real estate. The smallest impact on the price is exerted by hiring a real estate agent.

In the conducted studies attention was paid to the "students' apartments" and months with the strongest traffic in the real estate market. On the basis of the collected data, it was stated that the most popular is the rental of an apartment with 2 rooms. The most selected urban units include Prądnik Czerwony, Krowodrza Nowa Wieś and the Stare Miasto. It has also been noticed that the price for the rental of $1 \mathrm{~m}^{2}$, decreases along with the number of rooms and surface of the apartment. Thanks to the simulation of credit repayment and the evaluation of apartments rented by students it was reported that the most beneficial option for the lessor is to purchase and rent an apartment with 1 room.

\section{References}

[1] Dudzińska M., Jasińska E., Kocur-Bera K., Leń P., Preweda E., Sajnóg N., Sobolewska-Mikulska K., Steinsholt H., Walacik M., Wójcik J.: Directions for land management in rural areas. [in:] Directions for land management in rural areas (ed. K. Sobolewska-Mikulska). Croatian Information Technology Society GIS Forum, University of Warmia and Mazury, University of Silesia, Zagreb 2014, pp. 64-68.

[2] Frukacz M., Popieluch M., Preweda E.: Korekta cen nieruchomości ze względu na uptyw czasu w przypadku dużych baz danych. Infrastruktura i Ekologia Terenów Wiejskich, nr 4, 2011, pp. 213-226.

[3] Jasińska E., Preweda E., Ruchel J.: Modeling transaction prices of properties based on qualitative and quantitative features. Geomatics and Environmental Engineering, vol. 4, no. 3, 2010, pp. 51-59.

[4] Jasińska E.: Real Estate Due Diligence on the Example of the Polish Market. [in:] 14th SGEM GeoConference on Informatics, Geoinformatics and Remote Sensing 2.SGEM2014 Conference Proceedings, June 19-25, 2014, Vol. 2, 2014, pp. 419-426. 
[5] Jasińska E.: Wybrane metody statystyczne w analizie rynku nieruchomości. Wydawnictwa AGH, Kraków 2012.

[6] Krajowy Rynek Nieruchomości, http://www.krn.pl.

[7] Preweda E.: Rachunek wyrównawczy $\Rightarrow$ modele statystyczne. Progres, Kraków 2013.

[8] Źróbek S., Kucharska-Stasiak E., Trojanek M., Adamiczka J., Budzyński T., Cellmer R., Dąbrowski J., Jasińska E., Preweda E., Sajnóg N.: Current problems of valuation and real estate management by value (ed. R. Cellmer), Croatian Information Technology Society GIS Forum, University of Warmia and Mazury, University of Silesia, Zagreb 2014, pp. 92-95. 